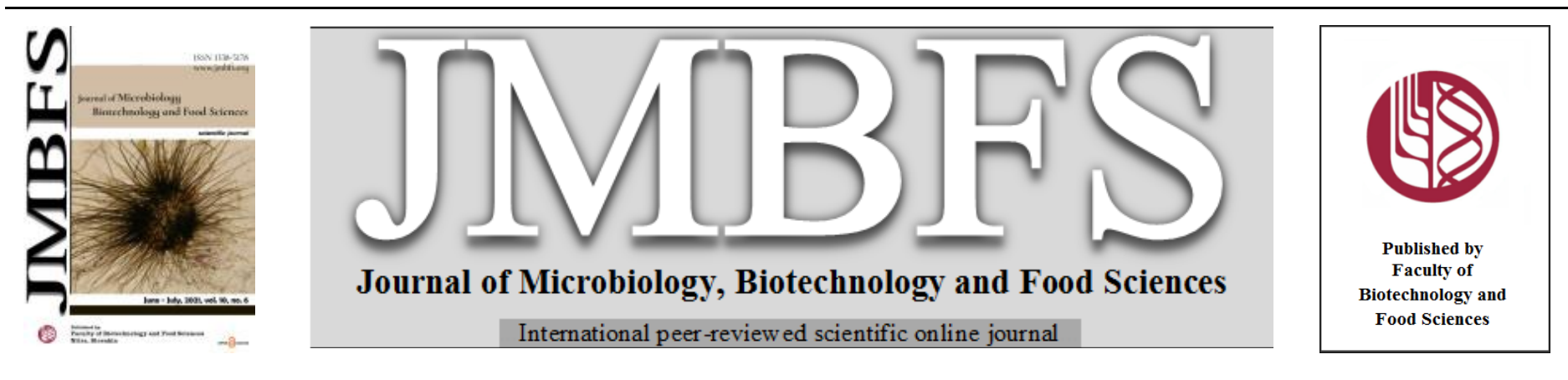

\title{
REDUCTION OF BIOGENIC AMINES PRODUCTION IN CHILLED MINCED MEAT USING ANTIMICROBIAL SEASONINGS
}

\author{
Abdallah Fikry A. Mahmoud ${ }^{{ }^{*}}$, Nermeen F. Elshopary ${ }^{2}$, Gamal R. Hasab El-Naby ${ }^{2}$, Rasha M. El Bayomi ${ }^{1}$
}

Address(es):

${ }^{1}$ Department of Food Control, Faculty of Veterinary Medicine, Zagazig University, El-Zeraah Str. 114, 44519-Zagazig, Egypt.

${ }^{2}$ Animal Health Research Institute, Tanta Provincial Laboratory, Tanta, Egypt.

*Corresponding author: abdallah.fikry90@gmail.com

https://doi.org/10.15414/jmbfs.3663

\section{ARTICLE INFO}

Received 3. 9. 2020

Revised 16. 12. 2020

Accepted 28. 12. 2020

Published 1. 6. 2021

Regular article

OPEN $\partial$ ACCESS

\section{ABSTRACT}

In the present study, biogenic amines levels, microorganisms count, and sensory attributes were assessed in seasoned and unseasoned minced beef during chilling storage at $3 \pm 1^{\circ} \mathrm{C}$ over four consecutive days. Seasoning treatments consisted of black pepper, garlic powder, onion powder, soy sauce, lactic acid, and lemon juice. Biogenic amines concentrations in unseasoned and seasoned samples were analyzed by HPLC. Sensory assessment was acceptable with good scores for seasoned meat samples. The total amount of biogenic amines increased significantly as the storage period increased. The most abundant amine was cadaverine followed by putrescine, histamine, and tyramine. However, biogenic amines concentrations increased significantly less in seasoned meat samples compared to unseasoned samples, with the smallest increase observed in mince treated with lemon juice, lactic acid, and garlic powder. Concurrently, the seasoned samples exhibited significantly lower total aerobic bacterial, Enterobacteriaceae, and Staphylococcus counts compared to their unseasoned equivalents. These results suggest that the addition of antimicrobial seasonings during minced meat processing could improve quality and provide a safer product.

Keywords: Antimicrobials, Biogenic amines, HPLC, Seasoning treatments, Reduction

\section{INTRODUCTION}

Meat plays an important role in a healthy and well-balanced diet because of its richness in high biological value proteins, B complex vitamins, especially B12, iron, selenium, phosphorus, and zinc (Wood, 2017). The safety of meat has been recently at the forefront of societal considerations, and indications exist that major meat safety issues and challenges can continue in the future. These challenges include the necessity to prevent and reduce the frequency and concentration of traditional and emerging foodborne pathogens, which may be of increased virulence and food related stresses (Brashears and Chaves, 2017). Biogenic amines (BAs) are associated with the presence of contaminating microorganisms and their production is considered one of the bacteriological quality indicators of meat and meat products (Omanovic-Miklicanin and Valzacchi, 2017). These low-molecular-weight substances are formed mainly by enzymatic decarboxylation of specific amino acids present in meat through microbial enzyme activity during storage (Zhang et al., 2019). These enzymatic activities have been described in several groups of microorganisms, especially Enterobacteriaceae, Micrococcaceae, and Pseudomonadaceae (Balamatsia et al., 2006). The most prevalent BAs in meat and meat products are tyramine, cadaverine, putrescine, and histamine (Ruiz-Capillas and Jiménez-Colmenero, 2005). Their amounts and ratios have been proposed as an index of the hygienic conditions of raw materials and manufacturing practices because these quantities increase during microbial spoilage even during chilled storage (Triki et al., 2018; Algahtani et al., 2020).

Besides being an indicator of bacterial contamination, BAs may have toxic effects for the consumer (Munir and Badri, 2020). For instance, the ingestion of high levels of tyramine and histamine can cause migraine headaches and food poisoning, respectively (Hungerford, 2010). Although putrescine and cadaverine do not exert a direct toxic effect, they inhibit histamine- and tyramine-detoxifying enzymes and, consequently, enhance the toxicity of these amines (Önal, 2007). In addition, the simultaneous occurrence of biogenic polyamines, such as putrescine and cadaverine, can cause additional negative physiological effects, such as carcinogenicity; when these amines convert into stable carcinogenic Nnitroso compounds (Linares et al., 2016).

The determination of biogenic amines is laborious and complex because of the physicochemical properties of these compounds. A variety of rapid and reliable analytical methods for determination of BAs in meat and meat products have been developed during the last decade and they were collected in various reviews (Jairath et al., 2015; Papageorgiou et al., 2018; Ruiz-Capillas and Herrero, 2019). In addition, several articles have developed extraction techniques that can be more environmentally safe, using of less harmful, organic solvents combined with sensitive and selective analytical tools using mass spectrometer and tandem mass spectrometer detectors (Sirocchi et al., 2014; Molognoni et al., 2018; Chang et al., 2019; Wojnowski et al., 2019).

The development of appropriate manufacturing technologies to obtain products free or nearly free from BAs is a challenge for the meat industry. The formation of BAs in food has been prevented principally by inhibiting microbial growth through temperature that has been well established in biogenic amines control (Naila et al., 2010). Once formed, BAs are difficult to be eliminated by hightemperature treatment because of their thermal stability (Cardozo et al., 2011). An alternative approach is to inhibit microbial growth and decarboxylase activity to control BA formation. The emerging approaches include the use of microbial modeling (Cardenas et al., 2008; Emborg and Dalgaard, 2008), high hydrostatic pressures (Bolton et al., 2009), packaging techniques (Mohan et al., 2009), and the addition of natural preservatives and coatings (Saleh et al., 2017; Eldaly et al., 2018; Mahmoud, 2019).

The usage of seasonings to improve the microbiological and technological qualities of meat products has been proven as an effective processing and preservation method over the past 30 years. Acidic seasonings have recently become more popular as antimicrobial ingredients. Specifically, lactic acid can inhibit the growth of many types of food-spoilage bacteria, including gramnegative species of the families Enterobacteriaceae and Pseudomonadaceae, by decreasing microbial loads on meat products (Kotula and Thelappurate, 1994; Jensen et al., 2003). This antimicrobial effect was attributed to the reduction of the $\mathrm{pH}$ below the range required for microbial growth as well as to inhibition of the bacterial metabolism due to the presence of undissociated acid molecules (Alvarado and McKee, 2007). Spices and edible plants, such as garlic, onion and black pepper, are commonly used as seasoning agents in several Middle Eastern meat dishes (Gyawali and Ibrahim, 2014). Such seasoning agents have shown antimicrobial activity due to the presence of specific compounds, such as piperine in black pepper (Dorman and Deans, 2000) and allicin and organosulfur compounds in garlic and onion (Carson, 1987; Sallam et al., 2004). Moreover, lemon juice has shown synergistic antimicrobial effects when combined with black pepper in the raw meatball dish called cig kofte (Bingol $\boldsymbol{e} t$ 
al., 2011). Soy sauce seasoning has also displayed antimicrobial activity against food-spoilage bacteria and food-borne pathogens (Kataoka, 2005).

Despite the proven antimicrobial activity of these seasonings, their efficacy in inhibiting bacterial growth and BA formation in chilled meat has not been comparatively assessed. Therefore, the current study was planned to compare the antimicrobial activity of black pepper (P), garlic powder (GP), onion powder $(\mathrm{OP})$, soy sauce (SS), lactic acid (LA), and lemon juice (LJ) in raw minced meat, as well as their effect in BA formation. To this end, we determined bacterial counts for total aerobic bacteria, Staphylococcus and Enterobacteriaceae, and measured formation of the BAs (histamine, tyramine, cadaverine, and putrescine) in raw unseasoned and seasoned minced meat during storage at $3 \pm 1^{\circ} \mathrm{C}$ for four days.

\section{MATERIALS AND METHODS}

\section{Preparation of samples and seasonings treatments}

Fresh minced meat (ca. 1500g) was purchased from local markets in Tanta City, Gharbia governorate, Egypt. The meat was divided into six portions weighing $250 \mathrm{~g}$ each. Five portions were treated with different seasonings while one was kept unseasoned as a control sample. Seasoning treatments included lactic acid (LA), lemon juice (LJ), and mixtures combining black pepper (P) with garlic powder (GPP), onion powder (OPP), or soy sauce (SSP). Lactic acid, lemon juice, soy sauce, and onion powder were added to the minced meat to obtain concentrations of $2 \%(\mathrm{w} / \mathrm{w})$. Garlic and freshly crushed black pepper were addec to obtain final concentrations of 1.5 and $0.08 \%(w / w)$, respectively as previously described (Rhoades et al., 2013). All samples were packaged in separate sterile polyethylene bags and kept under chilling at $3 \pm 1{ }^{\circ} \mathrm{C}$. BAs and bacteriological changes were evaluated every $24 \mathrm{~h}$ during storage. The treatments and analyses were repeated 3 times using fresh ingredients each time.

\section{Determination of BAs}

Analytical standards of BAs, including histamine (C5H9N3), tyramine $(\mathrm{C} 8 \mathrm{H} 11 \mathrm{NO})$, putrescine $(\mathrm{C} 4 \mathrm{H} 12 \mathrm{~N} 2)$, and cadaverine $(\mathrm{C} 5 \mathrm{H} 14 \mathrm{~N} 2)$ together with Trichloroacetic acid (TCA) were purchased from Sigma-Aldrich Chemical Company (Germany). Sodium chloride $(\mathrm{NaCl})$, sodium hydroxide $(\mathrm{NaOH})$, and other chemicals used were obtained from El-Gomhouria Chemical Company (Cairo, Egypt). All chemicals used were of the highest quality available.

The BAs were analyzed from the same minced meat used for the bacteriological evaluation, in the Central Laboratory, Faculty of Veterinary Medicine, Benha University, according to the procedures of Maijala and Eerola (1993) with some modification. Each sample (25g) was thoroughly homogenized with $125 \mathrm{ml}$ of $5 \%$ trichloroacetic acid (TCA) for $3 \mathrm{~min}$ and then filtered using Whatman filter paper (No. 1). The filtrate $(5 \mathrm{~mL})$ was transferred into a suitable glass tube containing $4 \mathrm{~g}$ of $\mathrm{NaCl}$ and $1 \mathrm{~mL}$ of $50 \% \mathrm{NaOH}$. Next, the tube was shaken well for $2 \mathrm{~min}$ and centrifuged at $5000 \mathrm{rpm}$ for $5 \mathrm{~min}$, and then the supernatant was transferred to a separating funnel $(50 \mathrm{~mL})$. Then, $\mathrm{n}$-heptane $(15 \mathrm{~mL})$ was added to the funnel and extracted three times with $1 \mathrm{~mL}$ portions of $0.2 \mathrm{NHCl}$. The extracts were collected in a glass stoppered tube and evaporated to dryness using a water bath at $95^{\circ} \mathrm{C}$ with a gentle current of air. Biogenic amines concentrations were determined using an Agilent 1100 HPLC system (Agilent Technologies, Waldbronn, Germany, model G 1311A) equipped with a Waters 600 delivery apparatus. The liquid chromatographic separation was conducted using a reverse phase C18 Nucleosil column $(250 \times 4 \mathrm{~mm}, 10 \mu \mathrm{m}$ packing, Macherey-Naggl) Analytes were detected by UV (Model G 1314A) at $254 \mathrm{~nm}$ using a linear program of $25 \mathrm{~min}$ periods at a constant solvent flow rate of $1 \mathrm{~mL} / \mathrm{min}$. Data were integrated and recorded using Millennium Chromatography Manager software 2010 (Waters, Milford MA 01757).

\section{Bacteriological analyses}

A sample (25g) was taken aseptically from seasoned and unseasoned minced meat and homogenized using a sterile blender (Lab Blender 400; Seward Medical) in $0.1 \%$ sterile peptone water $(225 \mathrm{~mL})$ for $1 \mathrm{~min}$ at room temperature. For the microbial count, aliquots $(0.1 \mathrm{~mL})$ of serial decimal dilutions of the original homogenates were spread to the surface of the appropriate dry media Total aerobic bacterial counts (TBC) were determined on plate count agar (Merck code $1.05463, \mathrm{GmbH}$, Germany) after incubation for $48 \pm 2 \mathrm{~h}$ at $37^{\circ} \mathrm{C}$ (APHA, 1992). For Enterobacteriaceae counts, the aliquot $(1 \mathrm{~mL})$ was inoculated into molten $\left(45^{\circ} \mathrm{C}\right)$ violet-red bile glucose agar $(10 \mathrm{~mL}$, Oxoid code $\mathrm{CM} 485)$ and allowed to set. Next, an overlay of molten medium $(10 \mathrm{~mL})$ was added and then incubated at $30^{\circ} \mathrm{C}$ for $24 \mathrm{~h}$ (ISO 21528-2, 2004). Staphylococcus counts were evaluated on Baird-Parker agar medium (Oxoid code CM 0275) after incubation at $37^{\circ} \mathrm{C}$ for $24 \mathrm{~h}$ (ISO 6888-1, 1999). All plates were examined visually to identify typical colony types and morphological characteristics associated with each growth medium. The resulting numbers of bacteria (CFU) per gram were transformed into Log values.

\section{Sensory evaluation}

Sensory assessment of unseasoned and seasoned meat samples during storage period was carried out by a panel of five members of postgraduate students (Food Control Department, Faculty of Veterinary Medicine, Zagazig University, Egypt) using a 9-point descriptive scale (Excellent, 9; Very very good, 8; Very good, 7; Good, 6; Medium, 5; Fair, 4; Poor, 3; Very poor, 2; Very very poor, 1) to evaluate the overall acceptability (total sensory evaluation score) as a combination of odor, taste and appearance (Pearson and Tauber, 1984). The samples with a mean sensory evaluation score of less than 5 were assessed as unacceptable for consumption.

\section{Statistical analysis}

Statistical differences in the BA contents in the control and seasoned samples and their relation to the storage time were evaluated by analysis of variance (One-way ANOVA) accompanied with Duncan's significant difference test. The statistical analyses were conducted using the GLM procedure of SPSS software version 19 (SPSS Inc., Chicago, IL, USA). The model includes the fixed effect of seasoning treatments $(\mathrm{i}=1, \ldots .5)$ and the random effect of replicate and error. Data are presented as the mean $\pm \mathrm{SE}$, and significance was considered at a significance level $(P<0.05)$.

\section{RESULTS AND DISCUSSION}

\section{BAs in unseasoned meat samples during chilling storage}

The changes in BA concentrations were determined in fresh unseasoned minced meat during storage at $3 \pm 1^{\circ} \mathrm{C}$ for four days as shown in the figure 1 . The concentrations of all the BAs examined increased significantly over the storage period. Generally, cadaverine was the most abundant BA followed by histamine and putrescine, while tyramine was first detected on the second day of the storage period. Regarding the limits of detection (LOD) and limits of quantification (LOQ), the amines studied ranged from 0.02 to $0.06 \mathrm{mg} \cdot \mathrm{kg}^{-1}$ and 0.05 to 0.12 $\mathrm{mg} . \mathrm{kg}^{-1}$, respectively.

At the beginning of the storage period, the mean BA levels ranged from nondetected (tyramine) to $30.77 \pm 0.37 \mathrm{mg} \cdot \mathrm{kg}^{-1}$ (cadaverine). Tyramine and cadaverine contents of the unseasoned minced meat samples increased significantly to reach $60.40 \pm 5.49$ and $116.17 \pm 5.74 \mathrm{mg} \cdot \mathrm{kg}^{-1}$, respectively at the end of the storage period (day 4). Similarly, histamine and putrescine levels increased from $\left(31.50 \pm 0.49\right.$ to $\left.90.08 \pm 0.06 \mathrm{mg} \mathrm{kg}^{-1}\right)$ and from $(16.03 \pm 4.65$ to $\left.60.10 \pm 3.38 \mathrm{mg} \cdot \mathrm{kg}^{-1}\right)$, respectively by the $4^{\text {th }}$ day of storage. Furthermore, the tota amount of BAs (TABA) in the unseasoned samples progressively increased from $78.30 \pm 5.51$ (day 1) to $326.75 \pm 14.67 \mathrm{mg} \cdot \mathrm{kg}^{-1}$ (day 4). The increase in BA concentrations over the storage period (4 days) was smaller than anticipated and this may be attributed to the low storage temperature inhibiting bacterial growth and thus lower decarboxylase activity of the bacteria responsible for the BA production in meat (Komprda et al., 2001; Galgano et al., 2009).

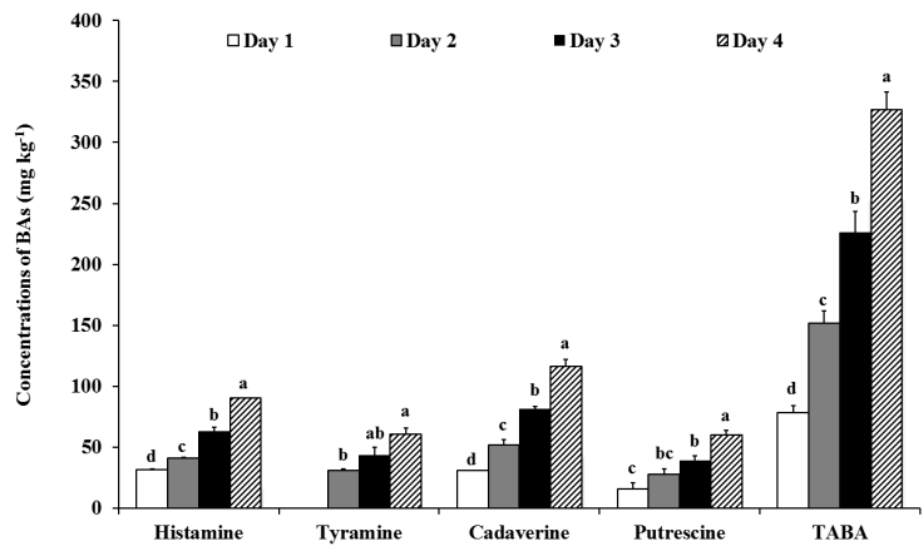

Figure 1 Average content of biogenic amines (Histamine, Tyramine, Cadaverine, and Putrescine) and total amount of biogenic amines (TABA) in unseasoned minced beef stored at $3 \pm 1^{\circ} \mathrm{C}$ for four consecutive days.

The obtained results were in good agreement with those achieved by Vinci and Antonelli (2002) who showed that cadaverine was the main amine found in bovine meat stored at $4^{\circ} \mathrm{C}$, followed by putrescine and tyramine (Min et al., 2004). However, the values obtained were 15 -fold higher (for cadaverine and putrescine) and 10-fold higher (for tyramine) than those reported in beef aerobically stored at $4^{\circ} \mathrm{C}$ for ten days (Li et al., 2016). Lower values were recorded respectively for tyramine (5-fold less) and histamine (7-fold less) in ground beef after ten days of chilling (Baston and Barna, 2016). Moreover lower values were obtained for cadaverine (23-fold less), putrescine (6-fold less), and TABA (12-fold less) in unpackaged fresh beef during storage at $4{ }^{\circ} \mathrm{C}$ for 12 
days (Kaniou et al., 2001). On the other hand, higher values were reported for putrescine (4.6-fold higher) and TABA (1.5-fold higher) in beef sausage stored at $4^{\circ} \mathrm{C}$ for 28 days (Rabie et al., 2014). These variations in BA concentrations could be attributed to raw meat quality, the availability of free amino acids, and the proportion of the microbial population with amino acid decarboxylase activity (Maijala et al., 1995; Santos, 1996). Despite these discrepancies, the individual BA contents are too low to reach toxic levels $\left(>50-100 \mathrm{mg} \cdot \mathrm{kg}^{-1}\right.$ for histamine (FDA, 2005); > 100-800 mg.kg ${ }^{-1}$ for tyramine) over the storage period (Eerola et al., 1997).

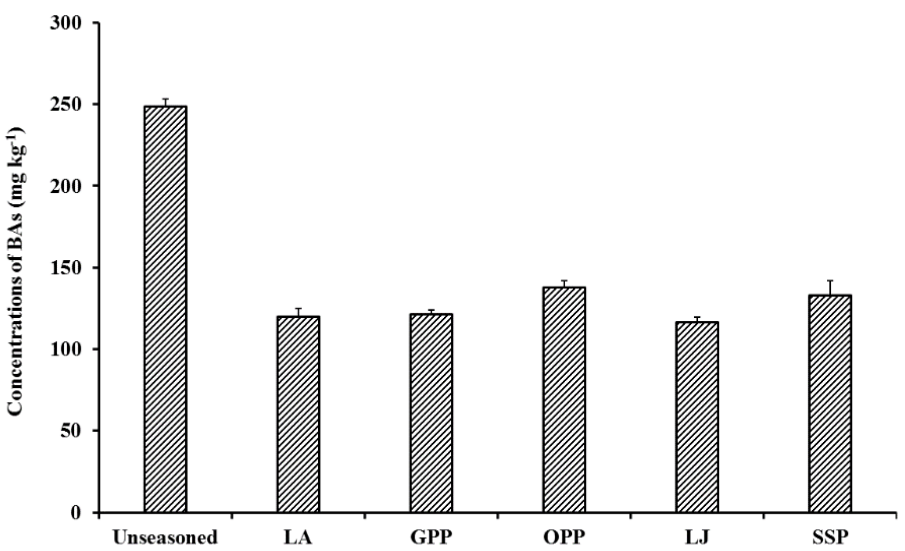

Figure 2 Increase in total amount of biogenic amines (TABA) in unseasoned and seasoned minced beef samples from day 1 to day 4 of storage. LA, lactic acid GPP, garlic powder mixed with black pepper; OPP, onion powder mixed with black pepper; LJ, lemon juice; SSP, soy sauce mixed with black pepper.

\section{BAs in seasoned minced meat samples during chilling storage}

BA concentrations were analysed in seasoned minced meat during storage at $3 \pm 1{ }^{\circ} \mathrm{C}$ for four days to assess how seasonings affected the production of BAs. In general, all tested seasonings reduced the BA concentrations at varying degrees. The results obtained in Table 1 revealed that the BA concentrations in seasoned samples were not significantly $(P>0.05)$ different except histamine at the beginning of storage ( $1^{\text {st }}$ day). BA values increased progressively with storage time and all seasoned samples were significantly $(P<0.05)$ lower than the control (unseasoned) samples at the end of the storage period $\left(4^{\text {th }}\right.$ day). Compared to the unseasoned samples, both LJ and GPP seasonings had a higher inhibitory effect on the production of histamine and putrescine. It was observed that histamine levels were decreased $(59 \%$ and $61 \%)$ while putrescine levels were decreased $(50 \%$ and $37 \%)$ in LJ and GPP seasoned samples, respectively. Moreover, LA and OPP seasonings worked best in controlling cadaverine formation, resulting in $64 \%$ and $58 \%$ reduction in cadaverine concentration, while SPP and GPP seasonings resulted in $34 \%$ and $30 \%$ reduction respectively in tyramine concentration at the end of the storage (day 4). Furthermore, the increase in TABA contents from day 1 to day 4 was calculated for each type of seasoning used. The difference in TABA in unseasoned and seasoned meat samples was presented in Fig 2. The TABA values were varied among the different seasonings as follows: LJ > LA > GPP > SSP > OPP. Additionally, best reduction results for TABA after the 4 days of storage were obtained with $\mathrm{LJ}$ and LA seasonings ( $44 \%$ reduction) followed by GPP ( $42 \%$ reduction) in comparison to the unseasoned samples. These findings agree with a previous study on the impact of additives on BA concentrations in meat and meat products, which showed that the largest effect was observed in cadaverine and putrescine contents (Jastrzebska et al., 2015). A similar reduction of BA production was observed when garlic and green onion extracts were added to the Korean salted and fermented anchovy Myeolchi-jeot (Mah et al., 2009). Overall, this suggests that the different effects observed for the specific BAs could be due to the seasonings differently affecting growth of different bacterial species during storage. Thus, the addition of these seasonings can decrease the production of BA in minced meat during the chilled storage.

Table 1 Quantification of BAs in minced meat samples during chilled storage at $3 \pm 1{ }^{\circ} \mathrm{C}$

\begin{tabular}{|c|c|c|c|c|c|}
\hline \multirow{2}{*}{ Seasonings /Time (days) } & \multicolumn{5}{|c|}{ Biogenic amine concentration $\left(\mathrm{mg} \mathrm{kg}^{-1}\right)$} \\
\hline & Histamine & Tyramine & Cadaverine & Putrescine & TABA \\
\hline \multicolumn{6}{|c|}{ First day } \\
\hline Control & $31.50 \pm 0.49^{\mathrm{a}}$ & nd & $30.77 \pm 0.37^{\mathrm{a}}$ & $16.03 \pm 4.65^{\mathrm{a}}$ & $78.30 \pm 5.51$ \\
\hline LA & $29.33 \pm 0.78^{\mathrm{ab}}$ & nd & $28.00 \pm 0.43^{\mathrm{a}}$ & $4.00 \pm 1.19^{\mathrm{a}}$ & $61.33 \pm 2.40$ \\
\hline GPP & $28.20 \pm 0.45^{\mathrm{ab}}$ & nd & $30.27 \pm 0.52^{\mathrm{a}}$ & $10.33 \pm 1.11^{\mathrm{a}}$ & $68.80 \pm 2.08$ \\
\hline OPP & $30.20 \pm 0.36^{\mathrm{ab}}$ & nd & $26.00 \pm 0.43^{\mathrm{a}}$ & $14.03 \pm 1.46^{\mathrm{a}}$ & $70.23 \pm 2.25$ \\
\hline LJ & $27.17 \pm 0.35^{\mathrm{b}}$ & nd & $30.00 \pm 1.19^{\mathrm{a}}$ & $10.33 \pm 0.53^{\mathrm{a}}$ & $67.50 \pm 2.07$ \\
\hline SSP & $29.27 \pm 0.54^{\mathrm{ab}}$ & nd & $29.00 \pm 0.91^{\mathrm{a}}$ & $14.00 \pm 1.19^{\mathrm{a}}$ & $72.27 \pm 2.64$ \\
\hline \multicolumn{6}{|c|}{ Second day } \\
\hline Control & $41.00 \pm 0.58^{\mathrm{a}}$ & $30.83 \pm 1.17^{\mathrm{a}}$ & $52.07 \pm 4.43^{\mathrm{a}}$ & $28.00 \pm 4.04^{\mathrm{a}}$ & $131.90 \pm 10.22$ \\
\hline LA & $29.00 \pm 0.65^{\mathrm{c}}$ & $30.00 \pm 1.47^{\mathrm{a}}$ & $30.50 \pm 0.34^{\mathrm{b}}$ & $24.33 \pm 1.62^{\mathrm{a}}$ & $113.83 \pm 4.08$ \\
\hline GPP & $29.73 \pm 0.29^{\mathrm{c}}$ & $26.33 \pm 2.76^{\mathrm{a}}$ & $42.20 \pm 0.70^{\mathrm{ab}}$ & $19.33 \pm 1.33^{\mathrm{a}}$ & $117.59 \pm 5.08$ \\
\hline OPP & $38.00 \pm 0.41^{\mathrm{b}}$ & $30.00 \pm 1.05^{\mathrm{a}}$ & $30.63 \pm 0.67^{b}$ & $27.03 \pm 2.03^{\mathrm{a}}$ & $125.66 \pm 4.16$ \\
\hline LJ & $28.10 \pm 0.40^{\mathrm{c}}$ & $30.10 \pm 0.43^{\mathrm{a}}$ & $39.03 \pm 1.19^{\mathrm{b}}$ & $18.33 \pm 1.62^{\mathrm{a}}$ & $115.56 \pm 3.64$ \\
\hline SSP & $30.43 \pm 0.32^{\mathrm{c}}$ & $25.07 \pm 1.20^{\mathrm{a}}$ & $37.00 \pm 1.47^{\mathrm{b}}$ & $29.00 \pm 2.33^{\mathrm{a}}$ & $121.50 \pm 5.32$ \\
\hline \multicolumn{6}{|c|}{ Third day } \\
\hline Control & $63.07 \pm 3.48^{\mathrm{a}}$ & $43.00 \pm 6.93^{\mathrm{a}}$ & $81.17 \pm 2.40^{\mathrm{a}}$ & $39.00 \pm 4.04^{\mathrm{a}}$ & $226.24 \pm 16.85$ \\
\hline LA & $36.27 \pm 0.33^{\mathrm{bc}}$ & $37.33 \pm 1.62^{\mathrm{a}}$ & $39.10 \pm 1.57^{b}$ & $36.33 \pm 1.62^{\mathrm{ab}}$ & $149.03 \pm 5.14$ \\
\hline GPP & $30.17 \pm 0.30^{\mathrm{c}}$ & $30.80 \pm 1.78^{\mathrm{a}}$ & $69.43 \pm 1.19^{\mathrm{a}}$ & $27.33 \pm 1.05^{\mathrm{ab}}$ & $157.73 \pm 4.32$ \\
\hline OPP & $42.33 \pm 0.78^{b}$ & $42.67 \pm 2.62^{\mathrm{a}}$ & $40.47 \pm 1.59^{\mathrm{b}}$ & $35.07 \pm 1.50^{\mathrm{ab}}$ & $160.54 \pm 6.49$ \\
\hline LJ & $31.03 \pm 0.35^{\mathrm{c}}$ & $38.80 \pm 2.59^{\mathrm{a}}$ & $50.40 \pm 1.46^{\mathrm{b}}$ & $23.37 \pm 1.04^{\mathrm{b}}$ & $143.60 \pm 5.44$ \\
\hline SSP & $43.17 \pm 0.36^{\mathrm{b}}$ & $33.33 \pm 3.19^{\mathrm{a}}$ & $46.33 \pm 1.62^{\mathrm{b}}$ & $36.40 \pm 1.31^{\mathrm{ab}}$ & $159.23 \pm 6.48$ \\
\hline \multicolumn{6}{|c|}{ Fourth day } \\
\hline Control & $90.08 \pm 0.06^{\mathrm{a}}$ & $60.40 \pm 5.49^{\mathrm{a}}$ & $116.17 \pm 5.74^{\mathrm{a}}$ & $60.10 \pm 3.38^{\mathrm{a}}$ & $327.75 \pm 14.67$ \\
\hline LA & $40.60 \pm 0.30^{\mathrm{cd}}$ & $48.00 \pm 2.61^{\mathrm{a}}$ & $42.23 \pm 2.33^{c}$ & $50.57 \pm 1.17^{\mathrm{ab}}$ & $181.40 \pm 7.31$ \\
\hline GPP & $34.90 \pm 0.40^{\mathrm{d}}$ & $42.33 \pm 0.78^{\mathrm{a}}$ & $74.83 \pm 2.13^{\mathrm{b}}$ & $38.00 \pm 1.47^{\mathrm{bc}}$ & $190.06 \pm 4.78$ \\
\hline OPP & $50.57 \pm 0.30^{\mathrm{bc}}$ & $58.37 \pm 1.79^{\mathrm{a}}$ & $49.00 \pm 3.19^{\mathrm{bc}}$ & $50.10 \pm 1.29^{\mathrm{ab}}$ & $208.04 \pm 6.57$ \\
\hline LJ & $36.93 \pm 0.43^{\mathrm{d}}$ & $46.00 \pm 1.47^{\mathrm{a}}$ & $70.67 \pm 2.33^{\mathrm{bc}}$ & $30.20 \pm 1.11^{\mathrm{c}}$ & $183.80 \pm 5.34$ \\
\hline SSP & $56.00 \pm 2.90^{\mathrm{b}}$ & $40.10 \pm 2.89^{\mathrm{a}}$ & $54.00 \pm 4.49^{\mathrm{bc}}$ & $54.97 \pm 1.43^{\mathrm{a}}$ & $205.07 \pm 11.71$ \\
\hline
\end{tabular}

* Mean values \pm standard errors were calculated using zero for non-determined (nd) values (below the detection limit). TABA, total amount of biogenic amines Mean values with different letters $(\mathrm{a}, \mathrm{b}, \mathrm{c}, \mathrm{d}, \mathrm{e})$ within a column are significantly different $(P<0.05)$ as measured by Duncan's test. 


\section{Bacterial counts}

The effect of the seasonings on the bacterial load of minced meat was assessed by monitoring TBC, Enterobacteriaceae, and Staphylococcus counts in unseasoned and seasoned meat samples kept under chilling at $3 \pm 1{ }^{\circ} \mathrm{C}$. Bacterial counts have been shown to increase gradually with storage time in all tested meat samples as compared to the previous day, regardless of the treatment. In general, the incorporation of seasoning agents during the preparation of minced meat resulted in significant $(P<0.05)$ reduction in TBC, Enterobacteriaceae and Staphylococcus counts when compared with control samples throughout storage. Specifically, the GPP, LJ and OPP seasoned samples exhibited the greatest inhibitory effect during the storage period followed by LA and SSP seasoned samples (Table 2).

Table 2 Bacterial counts expressed as $\left(\log \mathrm{CFU} \cdot \mathrm{g}^{-1}\right)$ in minced meat samples during chilled storage at $3 \pm 1{ }^{\circ} \mathrm{C}$.

\begin{tabular}{|c|c|c|c|}
\hline \multirow{2}{*}{$\begin{array}{l}\text { Seasonings } \\
\text { /Time (days) }\end{array}$} & \multicolumn{3}{|c|}{ Mean bacterial count (Mean \pm SE) } \\
\hline & $\begin{array}{c}\text { Total bacterial } \\
\text { count }\end{array}$ & $\begin{array}{c}\text { Enterobacteriaceae } \\
\text { count }\end{array}$ & $\begin{array}{c}\text { Staphylococcus } \\
\text { count }\end{array}$ \\
\hline \multicolumn{4}{|l|}{ First day } \\
\hline Control & $6.19 \pm 0.17^{\mathrm{a}}$ & $3.88 \pm 0.33^{\mathrm{a}}$ & $4.40 \pm 0.32^{\mathrm{a}}$ \\
\hline $\mathbf{L A}$ & $4.78 \pm 0.41^{\mathrm{b}}$ & $3.68 \pm 0.38^{\mathrm{ab}}$ & $3.84 \pm 0.24^{\mathrm{bc}}$ \\
\hline GPP & $4.36 \pm 0.71^{\mathrm{c}}$ & $2.46 \pm 0.27^{\mathrm{c}}$ & $2.92 \pm 0.28^{\mathrm{e}}$ \\
\hline OPP & $4.42 \pm 0.35^{\mathrm{c}}$ & $3.36 \pm 0.24^{\mathrm{b}}$ & $3.42 \pm 0.36^{\mathrm{d}}$ \\
\hline $\mathbf{L J}$ & $3.69 \pm 0.32^{\mathrm{d}}$ & $2.79 \pm 0.26^{\mathrm{c}}$ & $3.78 \pm 0.22^{\mathrm{c}}$ \\
\hline SSP & $4.82 \pm 0.34^{b}$ & $3.70 \pm 0.37^{\mathrm{ab}}$ & $4.06 \pm 0.39^{b}$ \\
\hline \multicolumn{4}{|l|}{ Second day } \\
\hline Control & $6.46 \pm 0.29^{\mathrm{a}}$ & $4.01 \pm 0.41^{\mathrm{a}}$ & $4.92 \pm 0.24^{\mathrm{a}}$ \\
\hline LA & $4.80 \pm 0.50^{\mathrm{b}}$ & $3.90 \pm 0.44^{\mathrm{a}}$ & $3.86 \pm 0.33^{\mathrm{c}}$ \\
\hline GPP & $4.75 \pm 0.56^{\mathrm{b}}$ & $2.78 \pm 0.29^{\mathrm{d}}$ & $2.93 \pm 0.22^{\mathrm{d}}$ \\
\hline OPP & $4.76 \pm 0.51^{\mathrm{b}}$ & $3.46 \pm 0.44^{\mathrm{b}}$ & $3.65 \pm 0.38^{\mathrm{c}}$ \\
\hline $\mathbf{L J}$ & $3.92 \pm 0.24^{\mathrm{c}}$ & $3.11 \pm 0.43^{\mathrm{c}}$ & $4.09 \pm 0.28^{\mathrm{b}}$ \\
\hline SSP & $4.88 \pm 0.36^{\mathrm{b}}$ & $3.82 \pm 0.33^{\mathrm{a}}$ & $4.09 \pm 0.30^{\mathrm{b}}$ \\
\hline \multicolumn{4}{|l|}{ Third day } \\
\hline Control & $7.87 \pm 0.40^{\mathrm{a}}$ & $4.82 \pm 0.50^{\mathrm{a}}$ & $6.08 \pm 0.37^{\mathrm{a}}$ \\
\hline LA & $5.26 \pm 0.25^{\mathrm{b}}$ & $4.08 \pm 0.37^{b}$ & $4.17 \pm 0.62^{\mathrm{b}}$ \\
\hline GPP & $5.10 \pm 0.66^{\mathrm{b}}$ & $2.79 \pm 0.28^{\mathrm{e}}$ & $3.30 \pm 0.30^{\mathrm{d}}$ \\
\hline OPP & $5.29 \pm 0.37^{b}$ & $3.73 \pm 0.32^{\mathrm{c}}$ & $3.93 \pm 0.27^{\mathrm{c}}$ \\
\hline $\mathbf{L J}$ & $4.01 \pm 0.41^{\mathrm{c}}$ & $3.13 \pm 0.24^{\mathrm{d}}$ & $4.11 \pm 0.24^{\mathrm{b}}$ \\
\hline SSP & $5.12 \pm 0.24^{\mathrm{b}}$ & $3.88 \pm 0.42^{\mathrm{bc}}$ & $4.22 \pm 0.25^{\mathrm{b}}$ \\
\hline \multicolumn{4}{|l|}{ Fourth day } \\
\hline Control & $\mathrm{R}$ & $\mathrm{R}$ & $\mathrm{R}$ \\
\hline LA & $5.46 \pm 0.63^{b}$ & $4.18 \pm 0.65^{\mathrm{a}}$ & $4.69 \pm 0.47^{\mathrm{a}}$ \\
\hline GPP & $5.83 \pm 0.26^{\mathrm{a}}$ & $3.52 \pm 0.45^{\mathrm{d}}$ & $3.90 \pm 0.39^{b}$ \\
\hline OPP & $5.98 \pm 0.29^{\mathrm{a}}$ & $3.93 \pm 0.30^{\mathrm{b}}$ & $4.16 \pm 0.48^{b}$ \\
\hline $\mathbf{L J}$ & $5.04 \pm 0.33^{c}$ & $3.69 \pm 0.35^{\mathrm{c}}$ & $4.49 \pm 0.34^{\mathrm{a}}$ \\
\hline SSP & $5.90 \pm 0.30^{\mathrm{a}}$ & $4.11 \pm 0.34^{\mathrm{a}}$ & $4.63 \pm 0.44^{\mathrm{a}}$ \\
\hline
\end{tabular}

R: Rejected (the total microbial load count exceeded 7 log CFU.g ${ }^{-1}$, and no further analyses were made).

CFU, Colony-forming unit

LA, lactic acid; GPP, garlic powder mixed with black pepper; OPP, onion powder mixed with black pepper; LJ, lemon juice; SSP, soy sauce mixed with black pepper.

Mean values with different letters within a column are significantly different $(P<0.05)$.

The total bacterial count of unseasoned minced meat samples reached $7.87 \mathrm{log}$ CFU.g ${ }^{-1}$ (above the acceptable limit $7 \log$ CFU.g ${ }^{-1}$ ) by the $3^{\text {rd }}$ day of storage with the objective signs of spoilage. Moreover, the Enterobacteriaceae and Staphylococcus counts displayed similar changes and increased significantly to 4.82 and $6.08 \log \mathrm{CFU} \cdot \mathrm{g}^{-1}$ on the $3^{\text {rd }}$ day of chilled storage, respectively. No further analyses were carried out on day 4 as the counts eventually increased in unseasoned samples and exceeded the acceptable limits.

Compared to the unseasoned samples, the seasoned meat samples presented significantly lower bacterial counts after just one day of treatment. In particular, the TBC, Enterobacteriaceae, and Staphylococcus counts of minced meat seasoned with LJ, GPP and OPP were significantly $(P<0.05)$ lower than other seasoned samples. In these samples, the TBC increased by $1.35,1.47$ and 1.56 $\log$ CFU.g ${ }^{-1}$, respectively from day 1 to day 4. However, the Enterobacteriaceae counts increased by $0.90,1.06$ and $0.57 \log$ CFU.g ${ }^{-1}$; whereas the Staphylococcus counts increased only by $0.71,0.98$ and $0.74 \log$ CFU.g ${ }^{-1}$, respectively from day 1 to day 4 .

The findings indicate that the seasonings tested minimize microbial growth in meat samples, maintaining bacterial growth below $6 \log \mathrm{CFU} \cdot \mathrm{g}^{-1}$. This is consistent with the results of Istrati et al. (2011) who showed that the addition of different spices and garlic when marinating beef decreases the growth of mesophilic aerobic bacteria. Decreased bacterial counts are possibly due to the acidity of the seasonings, which lowers the $\mathrm{pH}$ of the meat and suppresses microbial activity, combined with the low temperature during chilled storage (Silva et al., 1999). According to Nogueira et al. (2003), the antimicrobia activity of organic acids, such as lactic acid and citric acid in lemon juice, results from two critical factors: these acids reduce the $\mathrm{pH}$ below the growth range and inhibit metabolic processes in their undissociated form. In addition, seasoning solutions containing soy sauce have also been shown to control spoilage microflora (Kargiotou et al., 2011; Reham, 2015).

\section{Sensory assessment of the unseasoned and seasoned samples}

In general, the sensory assessment is the primary quality guide from the consumer's point of view perspective. Therefore, it is advantageous to compare the sensory characteristics for unseasoned and seasoned meat samples. The overall acceptability score for sensory attributes was significantly $(p<0.05)$ higher for seasoned meat samples compared to unseasoned group. The data presented in figure 3 showed that the samples seasoned with LA, GPP, OPP, LJ and SPP seasonings resulted in significant improvements of the sensory characteristics of minced meat samples during chilled storage, as such seasonings comprise antioxidant substances that enhance meat color and flavor (VlakhovaVangelova and Dragoev, 2014). These findings were in accordance with Istrati et al. (2011) who found that the sensory properties of meat could be improved by addition of seasonings. Specifically, samples seasoned with lemon juice showed the highest improvement of sensory characteristics. These results agree with Reham (2015) who reported that samples seasoned with lemon juice for $48 \mathrm{hrs}$ revealed the highest improvement of sensory attributes.

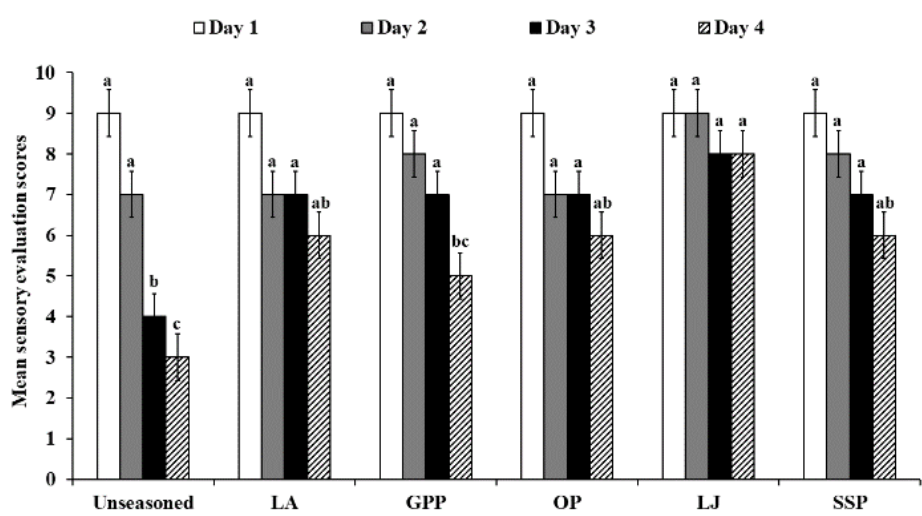

Figure 3 Changes in sensory characteristics (overall acceptability) of unseasoned and seasoned minced beef samples during cold storage at $3 \pm 1^{\circ} \mathrm{C}$ for four consecutive days. Columns carrying different superscript letters within the same day are significantly different $(P<0.05)$.

\section{CONCLUSION}

The present study showed that BAs formation in minced meat during chilled storage could be inhibited using selective seasonings. In particular, acidic seasonings, such as lemon juice and lactic acid, displayed the highest inhibitory effects for histamine, tyramine, cadaverine, and putrescine formation in meat samples during storage at $3 \pm 1^{\circ} \mathrm{C}$. The seasoned samples had significantly lower bacterial counts than their unseasoned counterparts over the entire storage period. Seasoned meat samples resulted in a significant improvement of sensory attributes. It could be concluded from the current study that natural seasonings (lemon juice, GPP and OPP) were the most effective in reducing microbial counts and biogenic amines content, thus consequently improving the safety of minced meat.

Acknowledgements: The authors are grateful for financial support from the Ministry of Higher Education and Scientific Research (MHESR), Egypt.

\section{REFERENCES}

Algahtani, F. D., Morshdy, A. E., Hussein, M. A., Abouelkheir, E. S., Adeboye, A., Valentine, A., \& Elabbasy, M. T. (2020). Biogenic Amines and Aflatoxins in Some Imported Meat Products: Incidence, Occurrence, and Public Health Impacts. Journal of Food Quality, 2020, 8718179. https://doi.org/10.1155/2020/8718179

Alvarado, C., \& McKee, S. (2007). Marination to improve functional properties and safety of poultry meat. Journal of Applied Poultry Research, 16(1), 113-120. https://doi.org/10.1093/japr/16.1.113

APHA (1992). Compendium Methods for the microbiological examination for foods pp.75-97, 239-250 and 325-420 APHA. Washington, D.C., U.S.A. 
Balamatsia, C. C., Paleologos, E. K., Kontominas, M. G., \& Savvaidis, I. N (2006). Correlation between microbial flora, sensory changes and biogenic amines formation in fresh chicken meat stored aerobically or under modified atmosphere packaging at $4{ }^{\circ} \mathrm{C}$ : Possible role of biogenic amines as spoilage indicators. Antonie van Leeuwenhoek, International Journal of General and Molecular Microbiology, 89(1), 9-17. https://doi.org/10.1007/s10482-005-9003$\underline{4}$

Baston, O., \& Barna, O. (2016). Biogenic amine amount in ground pork and beef meat. Food and Environment Safety Journal, 13(2).

Bingol, E., Cetin, O., \& Muratoglu, K. (2011). Effect of lemon juice on the survival of Salmonella Enteritidis and Escherichia coli in cig kofte (raw meatball). British Food Journal, 113(9), 1183-1194. https://doi.org/10.1108/00070701111174604

Bolton, G. E., Bjornsdottir, K., Nielsen, D., Luna, P. F., \& Green, D. P. (2009) Effect of high hydrostatic pressure on histamine forming bacteria in yellowfin tuna and mahi-mahi skinless portions. In Institute of Food Technologists (IFT) Conference (Pp. 006-05).

Brashears, M. M., \& Chaves, B. D. (2017). The diversity of beef safety: A global reason to strengthen our current systems. Meat Science, 132, 59-71. https://doi.org/https://doi.org/10.1016/j.meatsci.2017.03.015

Cardenas, F. C., Giannuzzi, L., \& Zaritzky, N. E. (2008). Mathematical modelling of microbial growth in ground beef from Argentina. Effect of lactic acid addition, temperature and packaging film. Meat Sci, 79(3), 509-520. https://doi.org/10.1016/j.meatsci.2007.12.003

Cardozo, M., Souza, S. P. de, Lima, K. dos S. C., \& Lima, A. L. dos S. (2011) Degradation of biogenetic amines by gamma radiation process and identification by GC/MS. INAC 2011: International nuclear atlantic conference Nuclear energy: new jobs for a better life, Brazil.

Carson, J. F. (1987). Chemistry and biological properties of onions and garlic. Food Reviews International, 3(1-2), 71-103. https://doi.org/10.1080/87559128709540808

Chang, Q., Zang, X., Wu, T., Wang, M., Pang, Y., Wang, C., \& Wang, Z. (2019). Use of functionalized covalent organic framework as sorbent for the solid-phase extraction of biogenic amines from meat samples followed by high-performance liquid chromatography. Food Analytical Methods, 12(1), 1-11.

Dorman, H. J., \& Deans, S. G. (2000). Antimicrobial agents from plants: antibacterial activity of plant volatile oils. Journal of Applied Microbiology, 88(2), 308-316. https://doi.org/10.1046/j.1365-2672.2000.00969.x

Eerola, S., Sagués, A. X. R., Lilleberg, L., \& Aalto, H. (1997). Biogenic amines in dry sausages during shelf-life storage. Zeitschrift Für Lebensmitteluntersuchung Und -Forschung A, 205(5), 351-355. https://doi.org/10.1007/s002170050179

Eldaly, E. A., Mahmoud, A. F. A., \& Abobakr, H. M. (2018). Preservative effect of chitosan coating on shelf life and sensory properties of chicken fillets during chilled storage. Journal of Nutrition and Food Security, 3(3), 139-148.

Emborg, J., \& Dalgaard, P. (2008). Modelling the effect of temperature, carbon dioxide, water activity and $\mathrm{pH}$ on growth and histamine formation by Morganella psychrotolerans. International Journal of Food Microbiology, 128(2), 226-233. https://doi.org/10.1016/j.ijfoodmicro.2008.08.016

FDA (2005). Compliance Policy Guide (CPG) Sec. 540.525 Decomposition and histamine - raw, frozen tuna and mahi-mahi; canned tuna; and related species. Galgano, F., Favati, F., Bonadio, M., Lorusso, V., \& Romano, P. (2009). Role of biogenic amines as index of freshness in beef meat packed with different biopolymeric materials. Food Research International, 42(8), 1147-1152. https://doi.org/10.1016/J.FOODRES.2009.05.012

Gyawali, R., \& Ibrahim, S. A. (2014). Natural products as antimicrobial agents. Food Control, 46, 412-429. https://doi.org/10.1016/j.foodcont.2014.05.047

Hungerford, J. M. (2010). Scombroid poisoning: A review. Toxicon, 56(2), 231243. https://doi.org/10.1016/J.TOXICON.2010.02.006

ISO21528-2. (2004). Microbiology of food and animal feeding stuffs Horizontal methods for the detection and enumeration of Enterobacteriaceae -Part 2: Colony-count method. International Organization for Standardization, Geneva.

ISO6888-1. (1999). Microbiology of food and animal feeding stuffs -- Horizontal method for the enumeration of coagulase-positive staphylococci (Staphylococcus aureus and other species) -- Part 1: Technique using Baird-Parker agar medium. Istrati, D., Constantin, O., Ionescu, A., Vizireanu, C., \& Dinica, R. (2011). Study of the combined effect of spices and marination on beef meat vacuum packaged The Annals of the University of Dunarea de Jos of Galati. Fascicle VI. Food Technology, 35(2), 75 .

Jairath, G., Singh, P. K., Dabur, R. S., Rani, M., \& Chaudhari, M. (2015), Biogenic amines in meat and meat products and its public health significance: a review. Journal of Food Science and Technology, 52(11), 6835-6846. https://doi.org/10.1016/j.microc.2018.10.034

Jastrzebska, A., Kowalska, S., \& Szłyk, E. (2015). Studies of levels of biogenic amines in meat samples in relation to the content of additives. Food Additives \& Contaminants. Part A, Chemistry, Analysis, Control, Exposure \& Risk Assessment, 33. https://doi.org/10.1080/19440049.2015.1111525

Jensen, J., Robbins, K., Ryan, K., Homco-Ryan, C., McKeith, F., \& Brewer, M (2003). Effects of lactic and acetic acid salts on quality characteristics of enhanced pork during retail display. Meat Science, 63(4), 501-508. https://doi.org/10.1016/S0309-1740(02)00111-0

Kaniou, I., Samouris, G., Mouratidou, T., Eleftheriadou, A., \& Zantopoulos, N. (2001). Determination of biogenic amines in fresh unpacked and vacuum-packed beef during storage at 4 degrees C. Food Chemistry, 74(4), 515-519. https://doi.org/10.1016/s0308-8146(01)00172-8

Kargiotou, C., Katsanidis, E., Rhoades, J., Kontominas, M., \& Koutsoumanis, K. (2011). Efficacies of soy sauce and wine base marinades for controlling spoilage of raw beef. Food Microbiology, 28(1), 158-163. https://doi.org/https://doi.org/10.1016/i.fm.2010.09.013

Kataoka, S. (2005). Functional effects of Japanese style fermented soy sauce (shoyu) and its components. Journal of Bioscience and Bioengineering, 100(3), 227-234. https://doi.org/10.1263/JBB.100.227

Komprda, T., Neznalovà, J., Standara, S., \& Bover-Cid, S. (2001). Effect of starter culture and storage temperature on the content of biogenic amines in dry fermented sausage poličan. Meat Science, 59(3), 267-276. https://doi.org/10.1016/S0309-1740(01)00079-1

Kotula, K. L., \& Thelappurate, R. (1994). Microbiological and Sensory Attributes of Retail Cuts of Beef Treated with Acetic and Lactic Acid Solutions Journal of Food Protection, 57(8), 665-670. https://doi.org/10.4315/0362-028X$\underline{57.8 .665}$

Li, S., Johansson, M., Vidanarachchi, J. K., Pickova, J., \& Zamaratskaia, G. (2016). Determination of biogenic amines in aerobically stored beef using highperformance thin-layer chromatography densitometry. Acta Agriculturae Scandinavica, Section A - Animal Science, 66(4), 199-205. https://doi.org/10.1080/09064702.2017.1315455

Linares, D. M., del Rio, B., Redruello, B., Ladero, V., Martin, M. C., Fernandez, M., Ruas-Madiedo, P., \& Alvarez, M. A. (2016). Comparative analysis of the in vitro cytotoxicity of the dietary biogenic amines tyramine and histamine. Food Chemistry, 197, 658-663. https://doi.org/10.1016/J.FOODCHEM.2015.11.013

Mah, J.-H., Kim, Y. J., \& Hwang, H.-J. (2009). Inhibitory effects of garlic and other spices on biogenic amine production in Myeolchi-jeot, Korean salted and fermented anchovy product. Food Control, 20(5), 449-454. https://doi.org/10.1016/J.FOODCONT.2008.07.006

Mahmoud, A. (2019). Effect of Lettuce, Marjoram and Cumin Essential Oils on the Quality and Shelf Life of Minced Meat during Refrigerated Storage. Zagazig $\begin{array}{llll}\text { Veterinary } & \text { Journal, } & \text { 47(3), } & \end{array}$ https://doi.org/10.21608/zvjz.2019.13680.1047

Maijala, R, Nurmi, E., \& Fischer, A. (1995). Influence of processing temperature on the formation of biogenic amines in dry sausages. Meat Science, 39(1), 9-22. https://doi.org/https://doi.org/10.1016/0309-1740(95)80003-4

Maijala, R. \& Eerola, S. (1993). Contaminant lactic acid bacteria of dry sausages produce histamine and tyramine. Meat Science, 35(3), 387-395. https://doi.org/10.1016/0309-1740(93)90043-H

Min, J. S., Lee, S. O., Jang, A., Lee, M., \& Kim, Y. (2004). Production of biogenic amines by microflora inoculated in meats. Asian-Australasian Journal of Animal Sciences, 17(10), 1472-1478. https://doi.org/10.5713/ajas.2004.1472

Mohan, C. O., Ravishankar, C. N., Gopal, T. K. S., Kumar, K. A., \& Lalitha, K. V. (2009). Biogenic amines formation in seer fish (Scomberomorus commerson) steaks packed with $\mathrm{O} 2$ scavenger during chilled storage. Food Research International, $42(3)$,

$411-416$

https://doi.org/https://doi.org/10.1016/j.foodres.2009.01.015

Molognoni, L., Daguer, H., de Sá Ploêncio, L. A., \& Lindner, J. D. D. (2018). A multi-purpose tool for food inspection: Simultaneous determination of various classes of preservatives and biogenic amines in meat and fish products by LCMS. Talanta, 178, 1053-1066. https://doi.org/10.1016/j.talanta.2017.08.081 Munir, M. A., \& Badri, K. H. (2020). The Importance of Derivatizing Reagent in Chromatography Applications for Biogenic Amine Detection in Food and Beverages. Journal of Analytical Methods in Chemistry, 2020 https://doi.org/10.1155/2020/5814389

Naila, A., Flint, S., Fletcher, G., Bremer, P., \& Meerdink, G. (2010). Control of biogenic amines in food--existing and emerging approaches. Journal of Food Science, 75(7), R139-50. https://doi.org/10.1111/j.1750-3841.2010.01774.x

Nogueira, M. C. L., Oyarzábal, O. A., \& Gombas, D. E. (2003). Inactivation of Escherichia coli O157:H7, Listeria monocytogenes, and Salmonella in cranberry, lemon, and lime juice concentrates. Journal of Food Protection, 66(9), $1637-$ 1641. https://doi.org/10.4315/0362-028X-66.9.1637

Omanovic-Miklicanin, E., \& Valzacchi, S. (2017). Development of new chemiluminescence biosensors for determination of biogenic amines in meat Food Chemistry, 235. https://doi.org/10.1016/j.foodchem.2017.05.031

Önal, A. (2007). A review: Current analytical methods for the determination of biogenic amines in foods. Food Chemistry, 103(4), 1475-1486. https://doi.org/10.1016/j.foodchem.2006.08.028

Papageorgiou, M., Lambropoulou, D., Morrison, C., Kłodzińska, E., Namieśnik, J., \& Płotka-Wasylka, J. (2018). Literature update of analytical methods for biogenic amines determination in food and beverages. TrAC - Trends in Analytical Chemistry, 98, 128-142. https://doi.org/10.1016/j.trac.2017.11.001 Pearson, A. M., \& Tauber, F. W. (1984). Analytical methods. In: Processed Meats, 2nd edn (edited by A.M. Pearson \& F.W. Tauber. Pp. 360- 361. Westport, CT: AVI Publishing. 
Rabie, M. A., Peres, C., \& Malcata, F. X. (2014). Evolution of amino acids and biogenic amines throughout storage in sausages made of horse, beef and turkey meats. Meat Science, 96(1), 82-87. https://doi.org/10.1016/j.meatsci.2013.05.042 Reham, A. A. (2015). Marination for controlling enterotoxigenic Staphylococcus aureus and its enterotoxins in broiler chicken breast fillets. Global Journal of Agriculture and Food Safety Sciences, 2, 156-173.

Rhoades, J., Kargiotou, C., Katsanidis, E., \& Koutsoumanis, K. P. (2013). Use of marination for controlling Salmonella enterica and Listeria monocytogenes in raw beef. Food Microbiology, 36(2), 248-253 https://doi.org/10.1016/J.FM.2013.06.010

Ruiz-Capillas, C., \& Jiménez-Colmenero, F. (2005). Biogenic amines in meat and meat products. Critical Reviews in Food Science and Nutrition, 44(7-8), 489-599. https://doi.org/10.1080/10408690490489341

Ruiz-Capillas, C., \& Herrero, A. (2019). Impact of biogenic amines on food quality and safety. Foods, 8(2). https://doi.org/10.3390/foods8020062

Saleh, E. A., Morshdy, A. E. M., Hafez, A. E., Hussein, M. A., Elewa, E. S., \& Mahmoud, A. F. A. (2017). Effect of pomegranate peel powder on the hygienic quality of beef sausage. Journal of Microbiology, Biotechnology and Food Sciences, 6(6). https://doi.org/10.15414/jmbfs.2017.6.6.1300-1304

Sallam, K. I., Ishioroshi, M., \& Samejima, K. (2004). Antioxidant and antimicrobial effects of garlic in chicken sausage. LWT-Food Science and Technology, 37(8), 849-855.

Santos, M. H. S. (1996). Biogenic amines: their importance in foods. International Journal of Food Microbiology, 29(2), 213-231. https://doi.org/https://doi.org/10.1016/0168-1605(95)00032-1

Silva, J. A., Patarata, L., \& Martins, C. (1999). Influence of ultimate pH on bovine meat tenderness during ageing. Meat Science, 52(4), 453-459. https://doi.org/10.1016/S0309-1740(99)00029-7

Sirocchi, V., Caprioli, G., Ricciutelli, M., Vittori, S., \& Sagratini, G. (2014) Simultaneous determination of ten underivatized biogenic amines in meat by liquid chromatography-tandem mass spectrometry (HPLC-MS/MS). Journal of Mass Spectrometry, 49(9), 819-825. https://doi.org/10.1002/jms.3418

Triki, M., Herrero, A., Jiménez-Colmenero, F., \& Ruiz-Capillas, C. (2018) Quality assessment of fresh meat from several species based on free amino acid and biogenic amine contents during chilled storage. Foods, 7(9). https://doi.org/10.3390/foods7090132

Vinci, G., \& Antonelli, M. L. (2002). Biogenic amines: quality index of freshness in red and white meat. Food Control, 13(8), 519-524.

Vlakhova-Vangelova, D., \& Dragoev, S. (2014). Marination: Effect on Meat Safety and Human Health. A review. Bulgarian Journal of Agricultural Science, 20(3), 503-509.

Wojnowski, W., Namieśnik, J., \& Płotka-Wasylka, J. (2019). Dispersive liquidliquid microextraction combined with gas chromatography-mass spectrometry for in situ determination of biogenic amines in meat: Estimation of meat's freshness. Microchemical Journal, 145, 130-138. https://doi.org/10.1016/j.microc.2018.10.034

Wood, J. D. (2017). Chapter 20 - Meat Composition and Nutritional Value. In F.

B. T.-L. M. S. (Eighth E. Toldra' (Ed.), Woodhead Publishing Series in Food Science, Technology and Nutrition (pp. 635-659). Woodhead Publishing. https://doi.org/10.1016/B978-0-08-100694-8.00020-0

Zhang, Y. jia, Zhang, Y., Zhou, Y., Li, G. hui, Yang, W. zhen, \& Feng, X. song. (2019). A review of pretreatment and analytical methods of biogenic amines in food and biological samples since 2010. Journal of Chromatography A, 1605, 360361. https://doi.org/10.1016/j.chroma.2019.07.015 